\title{
Chinese Airlines' Differences of Accounting Treatment Methods between Current Standards and the Latest International Accounting Leasing Standards: A Case Study of China Eastern Airlines
}

\author{
Chaoyu Lu \\ School of Economics and Management, Nanjing University of Science and Technology, Nanjing \\ 210094, China \\ akemi55707117@163.com
}

Keywords: Accounting treatment comparison; China Eastern Airlines; IFRS16.

Abstract: The promulgation of the latest international leasing standards has led to the merger of operating leases and financial leases, and requires the management of operating lease assets to be included in the table. The IFRS16 is about to take effect, which will have a significant impact on companies with large operating lease assets. At the same time, accounting treatment will also change, and relevant enterprises and industries should take measures to respond positively.

\section{Introduction}

\subsection{The meaning of the topic}

The promulgation of the latest International Financial Reporting Standards No. 16 (IFRS16) requires that operating lease assets be included in the table calculations, and no longer distinguish between operating leases and financial leases. Since IFRS16 will take effect on January 1, 2019, this will expose many companies with large operating lease assets (such as airlines), leasing industries and accounting standards setting bodies to the problem of how to deal with the impact of this lease accounting revision.

This article will take China Eastern Airlines as an example to compare and analyze the differences between current lease accounting standards and IFRS16 in accounting treatment methods, reflecting the impact of the implementation of the new standards on airlines.

\subsection{Revision background}

The revision of the IFRS16 leasing accounting standards is due to the fact that the current International Accounting Standards - Leasing (IAS17) stipulates that the two types of leasing are handled differently, and the different treatment methods of the same business result in poor comparability of financial information.

(1) Under the current leasing standards, the operating leases are reflected in the lessor's balance 
sheet, and the financial leases are reflected in the lessee's balance sheet.The different treatment methods of the leasing parties result in a decrease in the transparency of the quality of financial information between different enterprises, and the comparability is poor.

(2) The lessee's operating lease under the current standard is not required to be presented in the balance sheet and is only included in the notes to the statement. And the rent for each period of operating leases is included in the income statement, which makes the scale of assets and liabilities untrue.

\subsection{Main content}

(1) The core idea of IFRS16 is "combined into one", no longer distinguishing between operating leases and financial leases. Except for small leases and leases with a lease term of less than 12 months, all other leases need to be reflected in the company's balance sheet. (2) Adopting the using right model, when the lessee determines the use of the identifiable asset and has the right to obtain the majority of the benefits of the asset, the lessee can confirm the income of the business, and the lessee does not need to distinguish between operating lease income and financial lease income. (3) The lessee makes an initial measurement based on the present value of the payment for the lease business. In the subsequent measurement, the lessee mostly uses the straight-line method to calculate the depreciation of the asset, and the term is the shorter of the service life and the lease term. (4) The lessor will be able to continue to classify the lease business as an operating lease or a financial lease, and different accounting classifications can be handled for different lease businesses.

\section{Current status of China Eastern Airlines leasing business}

\subsection{Introduction to China Eastern Airlines}

China Eastern Airlines (CEA) is a state-owned holding airline headquartered in Shanghai, China. It was reorganized on the basis of the former China Eastern Airlines Group Corporation and merged with China Northwest Airlines and China Yunnan Airlines. Eastern Airlines is the first airline in China to be listed in HK, New York and Shanghai. It is one of the three major state-owned backbone airlines in China.

On March 30, 2018, CEA released its 2017 annual performance report. According to the Chinese Accounting Standards for Business Enterprises, CEA achieved operating income of 101.721 billion yuan in 2017, a year-on-year increase of 3.21\%; The total profit was 8.62 billion yuan, a year-on-year increase of 32.47\%; The net profit was 6.820 billion yuan, and the net profit attributable to shareholders of the parent company was 6.352 billion yuan, a year-on-year increase of $40.91 \%$.

\subsection{China Eastern Airlines Fleet structure}

In recent years, CEA has continued to optimize its fleet structure. In 2017, CEA introduced a total of 73 aircraft around the main models, and a total of 18 aircraft were withdrawn. With the introduction of the B737-8MAX aircraft and the successive withdrawal of the B767 aircraft, the company's fleet age structure has remained young.

As of December 31, 2017,CEA operated a total of 637 aircraft, including 627 passenger aircraft and 10 business jets. The company operates 145 aircraft rental aircraft, accounting for 23.13\% of the total number of aircraft. And in 2017, CEA introduced 26 aircraft through operating leases.According to the cost analysis table in the annual report, CEA 's operating lease expenses 
were 4.318 billion yuan in 2017. It can be seen that the lease occupies a large part of the aircraft assets, so for the financial status and operating performance of CEA, the leased assets will have a considerable impact on it.

\section{Differences in accounting treatment methods of China Eastern Airlines under IFRS16}

\subsection{Accounting treatment comparison between the lessor and the lessee under the current standards}

Airlines are more willing to choose operating leases because the airlines not only obtain the right to use the leased equipment such as aircraft, but also the operating leases are not reflected in the balance sheet, which can achieve the purpose of off-balance sheet financing. Therefore, operating leases are widely used in airlines and become an important method for enterprises to meet financing needs.

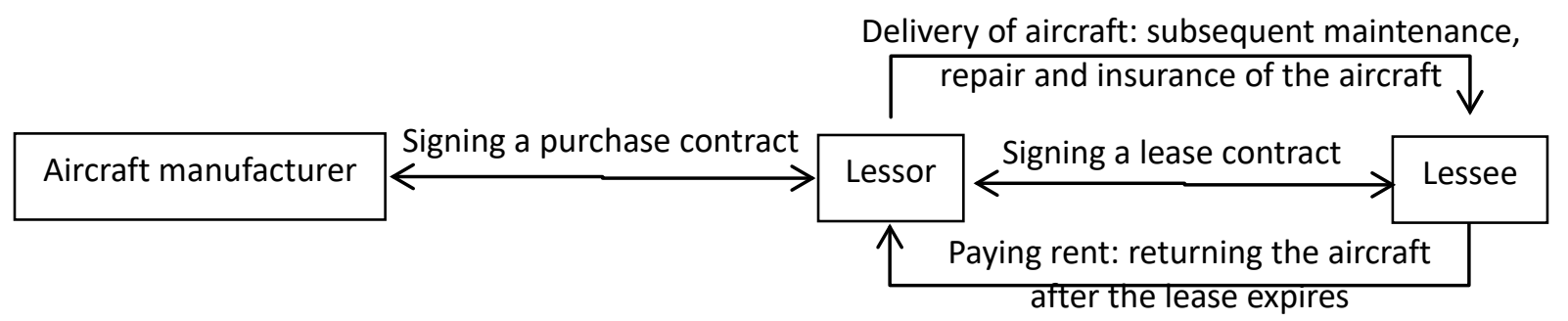

Fig.1 Rental Aircraft Flow Chart

According to Fig.1 and the current standards, the accounting treatment of the lessor and the lessee is shown in the following table.

Table 1 Accounting Treatment Comparison between Lessor and Lessee

\begin{tabular}{|c|c|}
\hline Lessor: a company & Lessee: China Eastern Airlines \\
\hline 1 Received the deposit: & 1 Paid the deposit: \\
\hline Dr: Cash in bank & Dr: Other receivables - operating lease deposit \\
\hline Cr: Other payables - operating lease deposit & Cr: Cash in bank \\
\hline 2 Confirm monthly operating lease income: & 2 Provision for monthly operating lease rent: \\
\hline Dr: Accounts receivable & Dr: Cost of sales \\
\hline Cr: Revenues - operating lease deposit & Cr: Accounts payable - operating lease deposit \\
\hline 3 Received operating lease rent: & 3 Paid operating lease rent: \\
\hline Dr: Cash in bank & Dr: Accounts payable - operating lease deposit \\
\hline Cr: Accounts receivable & Cr: Cash in bank \\
\hline \multicolumn{2}{|l|}{4 Depreciation of operating lease assets: } \\
\hline \multicolumn{2}{|l|}{ Dr: Cost of sales } \\
\hline \multicolumn{2}{|l|}{ Cr: Accumulated depreciation } \\
\hline
\end{tabular}

\subsection{Accounting treatment comparison of lessee between current standards and IFRS16}

Under the IFRS16, the lessor company follows the current standards and its accounting method remains unchanged. For CEA, it is necessary to confirm the lease assets and lease liabilities related 
to the lease business.

The IFRS16 lessee accounting method is very different from the current standards operating lease processing method, and is also slightly different from the current financing lease processing method. That is, instead of using unrecognized financing charges, the direct liability interest plus the lease liability is used, the rent is deducted from the lease liability, and the difference is repaid to the principal amount. Therefore, in accordance with the requirements of the IFRS16, for the subsequent measurement of operating leases, the paid rent is treated as the return of the lease liability and the payment of interest on the lease liability.

Accordingly, the lessee's accounting treatment comparison between current standards and IFRS16 are shown in Table 2.

Table 2 Accounting Treatment Comparison of Lessee

\begin{tabular}{|c|c|}
\hline Current standards & IFRS16 \\
\hline 1 Paid the deposit: & 1 Paid the deposit: \\
\hline $\begin{array}{l}\text { Dr: Other receivables - operating lease deposit } \\
\text { Cr: Cash in bank }\end{array}$ & $\begin{array}{l}\text { Dr: Other receivables - operating lease deposit } \\
\text { Cr: Cash in bank } \\
2 \text { On the lease inception day, confirm the leased } \\
\text { assets and lease liabilities: } \\
\text { Dr: Fixed assets - leased assets } \\
\text { Cr: Long-term payables - lease liabilities }\end{array}$ \\
\hline 2 Provision for monthly operating lease rent: & 3 Provision for monthly operating lease rent: \\
\hline $\begin{array}{l}\text { Dr: Cost of sales } \\
\quad \text { Cr:Accounts payable - operating lease deposit }\end{array}$ & $\begin{array}{l}\text { Dr: Cost of sales - leased assets depreciation } \\
\text { Cr: Accumulated depreciation } \\
4 \text { Provision for monthly interest on lease liability: } \\
\text { Dr:Financial expenses - interest on lease liabilities } \\
\text { Cr: Long-term payables - lease liabilities }\end{array}$ \\
\hline 3 Paid operating lease rent: & 5 Paid operating lease rent: \\
\hline $\begin{array}{l}\text { Dr:Accounts payable - operating lease deposit } \\
\text { Cr: Cash in bank }\end{array}$ & $\begin{array}{l}\text { Dr: Long-term payables - lease liabilities } \\
\text { Cr: Cash in bank }\end{array}$ \\
\hline
\end{tabular}

Under the current standards, the related business of CEA is not included in the balance sheet. However, under IFRS16, related business is included in the balance sheet: at the beginning of the lease, a lease asset and a lease liability are recognized; in the subsequent measurement, the leased assets need to be depreciated, and the lease liability affects its book value by accruing interest and rent payments.

At the same time, under the current standards, the lease expenses of CEA are directly included in the current profit and loss. However, under IFRS16, the lease expenses are divided into two parts: the interest calculated on the payment of the lease liability is a financial expense; Rent expenses as a repayment of the principal of the lease liability are not included in the accounting of the income statement.

In addition, operating activities under current standards have been transformed into financing activities under IFRS16.

\section{Summary}

This article focuses on the IFRS16 published in January 2016 and points out the problems of current leasing standards. This paper starts with the biggest change of the "using right model" proposed by IFRS16 and taking China Eastern Airlines as an example. Additionally, the difference between the accounting treatment of the lessor and the lessee and the accounting treatment before 
and after the change of the standards are explained. It is hope that through this article, people can have a systematic understanding of the newly released international leasing standard IFRS16.

Although the current implementation of the Chinese airline is still the old standard "Enterprise Accounting Standards No. 21 - Lease", the effective date of the new standard is January 1, 2019. Many airlines operate lease business with long term contracts, and the new standard requires retrospective adjustment of the company's existing operating lease business in the year of implementation, which will certainly have a huge impact on China's airlines with large operating lease assets. Therefore, our airlines should be prepared in advance to deal with the implementation of the new standards.

\section{References}

[1] Lielan Wu, Shujun Zhu. The Impact of New International Leasing Standards on Operating Leasing Business_-Taking Chunqiu Airlines as an Example [J]. Friends of Accounting, 2018(13):10-14.

[2] Yijie Huang. Analysis on the Application of New International Lease Accounting Standard_-Taking China Ocean Shipping Holdings Co., Ltd. as an Example[J]. Accounting Newsletter,2018(16):119-121.

[3] Wei Shen. Analysis of the impact of changes in international leasing standards on lessees [J]. Finance and Accounting, 2018 (11): 14-16.

[4] Xuefeng He, Xin Zhang, Jingli Chen, Xiaoya Wu. Major Changes in International Leasing Standards and Their Impact on Retail Industry_-Taking Chongqing Department Store as an Example[J]. Finance and Accounting Monthly, 2018(07): 113-117.

[5] Fenfang Qi. Research on leasing accounting issues [D]. Shenzhen University, 2017.

[6] Wenting Zhu, Yongbin Wu, Aimei Lin. Analysis of the Impact of Changes in International Leasing Standards on Air Transport Industry[J]. Accounting Newsletter,2017(01):109-111.

[7] Xuenian Cao. Analysis of the Impact of International Accounting Convergence on China and Countermeasures[J]. Modern Economic Information. 2017 (10): 240-240. 